\title{
A Produção Científica no Brasil
}

\author{
Cristina Muccioli, Mauro Campos, Mauro Goldchmit, Paulo E.C. Dantas, Samir J. Bechara, Vital Paulino Costa
}

A comunidade científica brasileira, especialmente a comunidade médica dedicada à pesquisa científica, se sentiu orgulhosa após a publicação de dados recentes sobre a produção brasileira. A CAPES (Coordenadoria de Aperfeiçoamento de Pessoal de Nível Superior) revelou um crescimento de $19 \%$ na produção científica brasileira no último ano, o que foi impulsionado sobretudo por estudos da área médica. Entre 2004 e 2005, o número de artigos publicados em periódicos indexados subiu de 13.313 para 15.777 , números obtidos a partir de dados do ISI (Institute for Scientific Information). Mais impressionante é o crescimento nos últimos 5 anos, equivalente a $49 \%$, o que deverá nos colocar na $15^{\underline{a}}$ posição mundial em 3 anos.

Há vários motivos para esse crescimento: nossos centros de pesquisa sempre estiveram equipados com material humano de altíssimo nível, porém o que sobrava em qualidade faltava em quantidade. Nas duas últimas décadas, o intercâmbio crescente com centros de pesquisa espalhados pelo mundo trouxe de volta ao Brasil um sem número de pesquisadores, todos aptos e ávidos para seguir investigando. Mais do que isso, o intercâmbio possibilitou conhecer a estrutura destes centros de pesquisa, que passaram a ser exemplos a serem seguidos. Com o apoio de órgãos voltados ao fomento à pesquisa (e aqui vale a pena ressaltar o papel da FAPESP, exemplo seguido mundialmente), foi mais fácil tornar essa estrutura uma realidade. Com estrutura montada e com mate- rial humano de alto nível, a produção científica cresce em PG, uma vez que novos pesquisadores vem se formando, num ciclo virtuoso que torna o país cada vez mais independente de tecnologia e apoio estrangeiros.

É lógico que nem tudo é perfeito e que há muito a melhorar. O número de patentes depositadas no país ainda deixa a desejar (somos o $27^{\circ}$ país nesse quesito), o que indica a necessidade de dar atenção à repercussão prática dos nossos investimentos na área científica. Não basta produzir artigos científi$\cos$, é fundamental que a pesquisa reverta em benefício para a comunidade que a incentiva: a patente é apenas parte dessa equação. Finalmente, faltou divulgar o impacto científico de nossas pesquisas. Esse impacto é medido pela freqüência com que os artigos aqui produzidos são citados por outros. De novo, não basta publicar um artigo, é importante que esse artigo tenha repercussão, que ele sirva de base para outras pesquisas na mesma área ou em áreas diferentes.

De todo modo, isso não tira o mérito dessa conquista da comunidade científica brasileira e só serve de estímulo para que sigamos nos envolvendo com pesquisa em oftalmologia. Os Arquivos Brasileiros de Oftalmologia se orgulham de servir de veículo científico para a Oftalmologia Brasileira há quase 70 anos. Esperamos continuar contando com os oftalmologistas brasileiros para tornar o produto de nossa pesquisa acessível a todo o mundo. 